\title{
Defect reduction of roof panel part in the export delivery process using the DMAIC method: a case study
}

Indra Setiawan*, Setiawan

Department of Industrial Engineering, Mercu Buana University, Jl. Meruya Selatan No. 1 Jakarta 11650, Indonesia

\section{ARTICLE INFORMATION \\ Article history: \\ Received: November 28, 2020 \\ Revised: December 22, 2020 \\ Accepted: December 28, 2020}

Keywords:

\section{Quality}

Defect

Six sigma

DMAIC

Roof panel

\section{A B $\quad \mathbf{S}$ T $\mathbf{R}$ A C $\mathbf{C}$}

Product quality has now become one of the main factors that every company must have to compete globally. One way is to reduce the number of defective products in the production process. This method is a continuous improvement effort made by PT Toyota Motor Manufacturing Indonesia and companies engaged in the automotive sector that produces cars. One of the processes is packing roof panels whose output will be sent to importing countries where the number of requests per month is relatively high but still has a high defect rate. Based on production data and defect data for the January-February 2019 period, roof panel packaging production has a 1\%-3\% defect rate. This company must reduce the defect rate to achieve the company target of zero defects. This study aims to improve the quality of the packaging process by minimizing the number of defective products. This study uses the Six Sigma method with DMAIC phases. This method has several phases, namely, Define, Measure, Analysis, Improvement, and Control. Corrective action to reduce product defects based on $5 \mathrm{~W}+1 \mathrm{H}$ is to formulate a repair plan at the upgrade phase, namely by making SOPs spraying anti-rust and supervising operators who produce roof panel packaging. The improvement results reduced the DPMO value from 33,500 units to 2,050 units and increased the sigma level from 3.33 to 4.37 . The DMAIC phase effectively controls and improves product quality levels in the automotive industry.

\section{*Corresponding Author}

Indra Setiawan

E-mail: indra.setiawan.2022@gmail.com

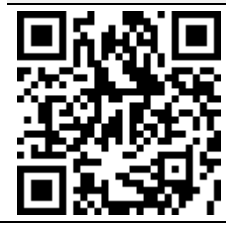

This is an open-access article under the CC-BY-NC-SA license.

\section{INTRODUCTION}

PT TMMIN is an industrial company engaged in the automotive sector. The main product of PT TMMIN is cars produced to meet the domestic market's needs and the export market. Cars sent by PT TMMIN to the export market are in Completely Build-Up (CBU) or intact and Completely Knock Down (CKD) or unraveled form. The production process at PT TMMIN has been arranged as best as possible to meet customer demand and achieve daily targets, such as in the production process for roof panel packaging parts in the Export Vaning Division (CEVD) Component.

The packaging process on the roof panel part has several processes, namely the roof panel part (Fig. 1) and a series of modules coming from the 
supplier. The parts and modules are processed to produce the roof panel part case output sent to the importer country. During January-February 2019, the defect rate in the roof panel's packaging process was $1 \%-3 \%$. This level of defect is not in accordance with the company's target of zero defect. Types of defects in the roof panels that occur are rust and scratches. If the problem is not resolved, it will impact the waste of raw materials, time, and energy [1].

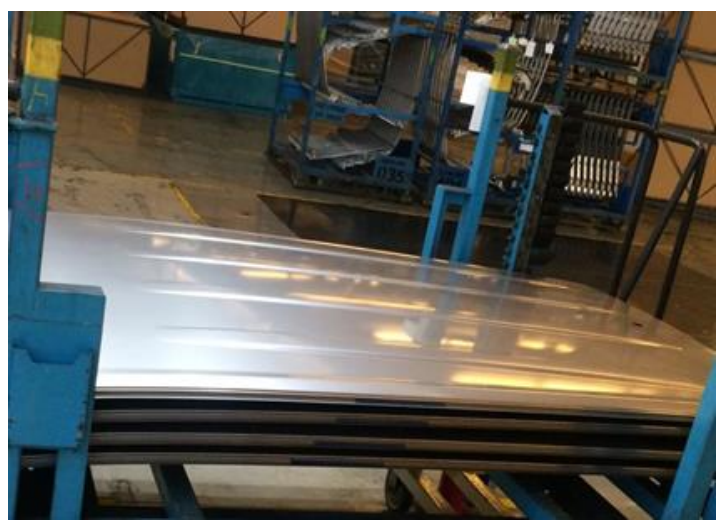

Fig. 1. Roof panel part

One method that can make improvements and improve quality is by using the DMAIC method. The Motorola company initially developed the DMAIC method as part of the Six Sigma framework, which is proven to eliminate defects and improve quality associated with business metrics [2], [3]. Six Sigma is a way to achieve operating performance of only 3.4 defects for every one million opportunities [4]-[6]. Before the Six Sigma process is carried out, the performance level is first measured, namely the DPMO level (Defect Per Million Opportunities) and the Sigma level's achievement (Sigma Level). Six Sigma implementation involves several integrated tools to get an increase in sigma value. The tools used in the six sigma DMAIC method include fishbone diagrams, SERVQUAL analysis and poka-yoke [7]; flow chart and observation [8]; Lean tools such as Value Stream Mapping (VSM) [9]-[11] and five whys analysis [12]; supplier, input, process, output and customer diagram (SIPOC), FMEA, Pareto diagram, causal analysis, and Gemba [13], [14].

Implementation of the Six Sigma DMAIC method can reduce the level of damage and increase the level of sigma [15]-[17]. The company advantage in applying this method can reduce costs tremendously [18]. This method is still developing in increasing productivity in the food and beverage industry [19], [20] and optimizing the production process in the textile industry [21]. The Six Sigma DMAIC method focuses on reducing process variability to produce high-quality products and creating an efficient process obtained without waste, resulting in added value for customers [22].

Referring to the successful application of the DMAIC method in automotive companies [23], [24], this study aims to improve quality by bringing the product to the lowest defect level to near perfection (zero defect). The application of DMAIC in PT TMMIN is expected to reduce the amount of damage to roof panel packaging parts and increase the company's profit.

\section{RESEARCH METHODS}

This research was conducted in the roof panel packaging section at PT TMMIN to reduce the number of defects using the DMAIC method (Define, Measure, Analyze, Improve, Control). The study uses secondary data, which includes production data from January to March 2019 and data on the number of production defects. DMAIC is used to improve product quality and reduce the number of defects. DMAIC is a process of continuous improvement towards Six Sigma targets (Fig. 2). The DMAIC phase is a phase that repeats or forms a quality improvement cycle with Six Sigma.

\subsection{Define phase}

This phase clearly defines, namely, the initial phase of implementing the DMAIC method to improve quality. At this phase, the activities are selecting and determining projects, determining problems and objectives, and making a SIPOC (Supplier-Input-Process-Output-Customer) diagram. The determination of the problem in this phase aims to improve the quality of specific processes.

\subsection{Measure phase}

. After the Six Sigma project is defined, then the critical characteristics of the product under study must also be defined. The activity carried out at this phase is to determine the CTQ with the Pareto diagram, previously calculating the percentage of defects with a formula:

$$
\begin{aligned}
& \% \text { of defects }=\frac{\text { Number of dent defect }}{\text { Total defects }} \times 100 \% . \\
& \bar{p}=\frac{\sum n p}{\sum n}
\end{aligned}
$$



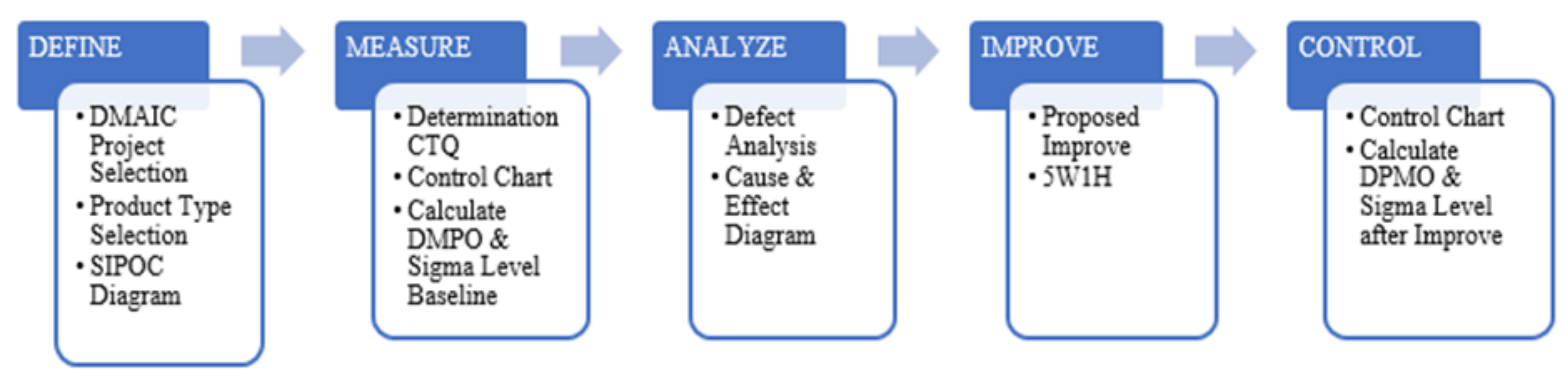

Fig. 2. DMAIC Method

$$
\begin{aligned}
& U C L=\bar{p}+3 \sqrt{\frac{\bar{p}(1-\bar{p})}{n}} \\
& L C L=\bar{p}-3 \sqrt{\frac{\bar{p}(1-\bar{p})}{n}}
\end{aligned}
$$

The calculation of Defects per Million Opportunities (DPMO) and Sigma Level.

Defect Per Opportunities (DPO)

$D P U=\frac{\mathrm{D}}{\mathrm{U}}$

Defect Per million Opportunities (DPMO)

$D P M O=D P O \times 10^{6}$

\subsection{Analyze phase}

At this phase, what needs to be done is to identify the sources and root causes of defect problems in the packaging process based on importer claims and then make a series of improvements to overcome these problems. The activities carried out at this phase are making a cause-and-effect diagram (Fishbone Diagram). Causal diagrams are useful for analyzing and finding factors that significantly influence the quality characteristics of work output.

\subsection{Improve phase}

The next phase is to improve. After the sources and root causes of quality problems have been identified, it is necessary to implement a corrective action plan to implement Six Sigma quality improvement. The steps taken in the Improve phase are to propose improvements using the $5 \mathrm{~W}+1 \mathrm{H}$ method.

\subsection{Control phase}

Control is the final phase in a Six Sigma quality improvement program. At this phase, it is an evaluation of the results of implementation. Control is done by creating a control chart to see whether the production process with the proposed improvement is statistically controlled or not. Control is also to determine the value of DPMO and sigma levels after improvement according to the measure phase formula.

\section{RESULTS AND DISCUSSION}

The case study relates to customer complaints regarding the roof panel packaging section at PT TMMIN. Customer complaints about this defect have an impact on the costs that must be borne by the company related to product replacement and return shipping. This study uses the DMAIC method to analyze and repair defects in the company's target zero defect. Solving this problem will significantly impact customer confidence and minimize defects from occurring in the future.

\subsection{Define phase}

The Define phase is the first operational step in the Six Sigma quality improvement program. Several steps are carried out at this phase, namely DMAIC Project Selection, Product Type Selection, and Preparation of the SIPOC Diagram. DMAIC Project Selection based on this research's considerations, this project was carried out at PT TMMIN in the packaging section. This project's selection was made because of the defects in the roof panel parts that had arrived in the importer's country. The packaging process results in the packaging of various parts sent to the importer country in Completely Knock Down (CKD). The parts are still in the decomposed form, which will then be assembled in the importer country. In January-February 2019, there were many Claim Importers on the type of roof panel parts caused by the packaging process, so there is a need for quality improvement in the process.

Preparation of the SIPOC Diagram using the roof panel packaging production process's data activity obtained by observation. The SIPOC diagram of the roof panel packaging production process (Fig. 3) explains the production flow of roof panels from suppliers to customers. In a series 


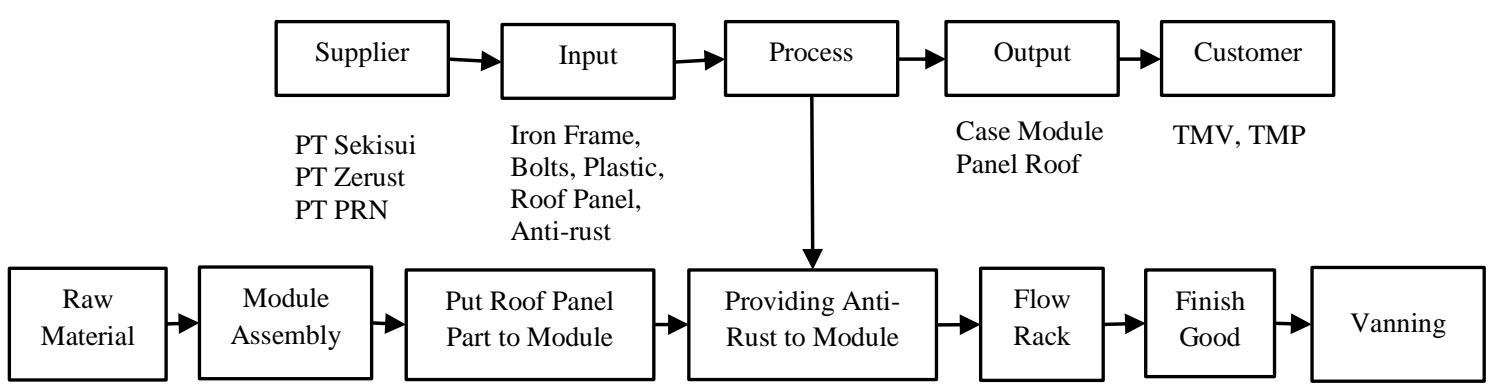

Fig. 3. SIPOC Diagram of the packaging production process

of roof panel packaging processes, the first starts from the supplier, namely the company that supplies the raw materials. These suppliers include PT PRN, PT Sekisui, and PT Zerust. Next, enter the input process carried out by the production process for roof panel packaging, namely the entry of iron frames, bolts, plastic, anti-rust, and roof panel parts. After that, the main production process for roof panel packaging is carried out in several phases, namely from raw material then processing the module assembly, placing the roof panel parts into the module, providing anti-rust plastic to the module, flow rack, finish good and vanning. The roof panel packaging part production process's output is a case containing parts to be sent to destination customers, namely importing countries, destinations such as TMV (Toyota Motor Vietnam) and TMP (Toyota Motor Philippines).

\subsection{Measure phase}

At this phase, measurements are made of the types of defects that have been identified. It will be necessary to determine the key characteristics that are important to the quality of the CTQ and calculate the Sigma Level of the defect rate per million opportunities for DPMO. Several steps are carried out at this stage, namely determination of Critical to Quality (CTQ), control chart, and measurement of DPMO and sigma level.

The determination of Critical to Quality (CTQ) is determined based on the specific needs of consumers. Consumers' customer requirements are smooth surface parts with no scratches, no defective body parts, no rust on parts, and the number of products sent according to the order. The choice of CTQ is based on the largest type of defect, which is known to have a major influence on product quality. Furthermore, it can be poured into the Pareto diagram to determine what types of defects are prioritized in improving product quality. The defects in the roof panel packaging processes based on customer claims consist of four types: dent, deform, rust, and shortage. Based on processing the complaint data entered using the Pareto diagram, rust has the largest percentage, which is $88.6 \%$ (Fig. 4). Claim Importer with shortage number of defects will be included in the other defect category.

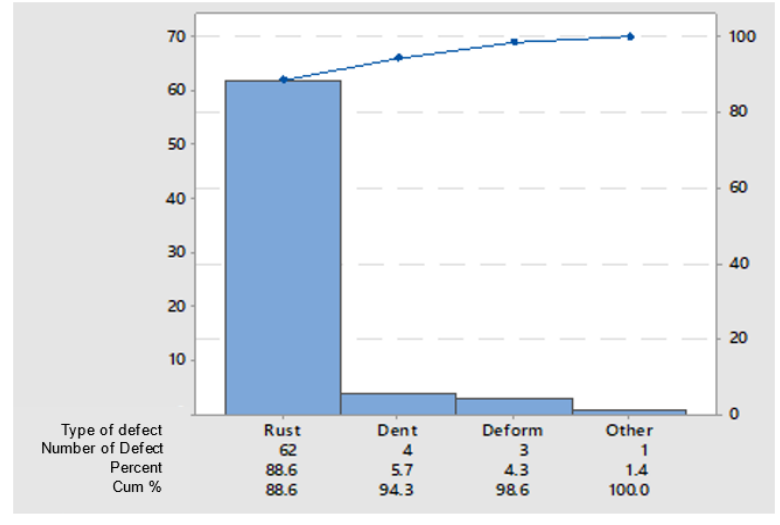

Fig. 4. Pareto diagram types of defects in the packaging process panel roof

In making this $\mathrm{p}$ control chart using data on the number of production and the number of defects that are very influential on the roof panel packaging process for the January-February 2019 period. With this data, the proportion of defects and control limits is calculated. After the calculations are carried out, a control chart is created to map these boundaries. The goal is to see whether the data is within the control or not. If there is data that is out of control, it must be recalculated to stabilize the process. From the P control chart (Fig. 5), it can be seen that all data is within control limits (in control). This shows that the packaging production process has been stable. Even though the packaging production process has been stable, the quality of priority defects must be improved so that the defect problem does not occur again. 


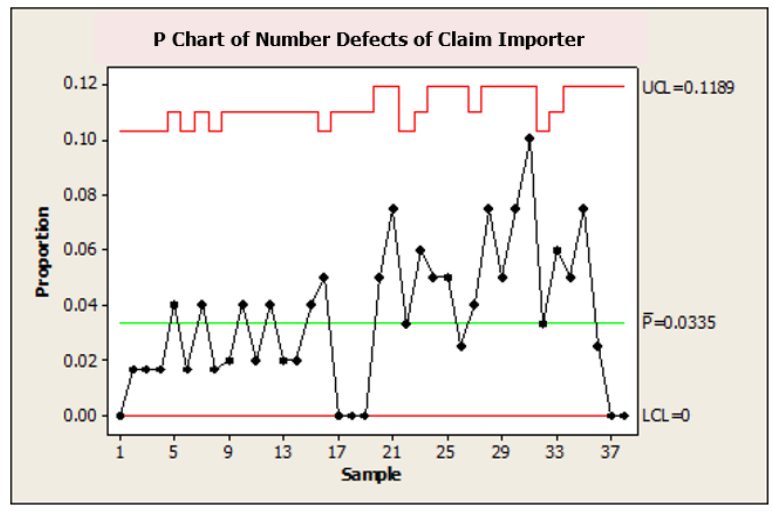

Fig. 5. Control chart of packaging panel roof process

The measurement unit results in the form of attribute data will be determined using the DPMO (Defects per Million Opportunities) measurement unit then converted from the DPMO value into the sigma level. The number of production of roof panel packaging in January-February 2019 is 1,850 units. Based on customer needs' characteristics, the types of characteristics of potential defects or CTQ, namely rust, can be seen. The type of defect produced means the chance of a defect in each unit of product produced. The number of defects in the production of roof panel packaging in January-February 2019 was 62 units. Based on the calculation, it is known that the number of defects per one million opportunities (DPMO) is 33,500 , meaning that there are still many rust defects in the roof panel packaging process. For the Sigma Level, the roof panel packaging process is at level 3.33.

\subsection{Analyze phase}

At this phase, analysis and identification of the main causes of the defect are carried out. Based on the making of the Pareto diagram and the $\mathrm{P}$ control chart, it is found that the type of defect that is very influential on CTQ is rust defect. Next will be an analysis of the root cause of the rust defect problem is. The tool used in this stage is the Fishbone diagram. Making this Fishbone diagram is an analysis and identification of the causes of rust defect problems based on brainstorming to line heads, operators, and field supervisors.

The cause of rust defects in the roof panel packaging process is caused by human factors, method factors, machine factors, and environmental factors. The human factor is caused by the operator's lack of knowledge about the quality's effect, applying anti-rust to the roof panel. The first method factor is the lack of anti-rust application on the roof panel, which will be coated with EVA foam. EVA foam is not given anti-rust; the second factor is an insufficient anti-rust application volume because there is no standard volume of anti-rust application. The anti-rust wear spraying machine causes the engine factor. Environmental factors caused by high humidity in the sea accelerate the process of rust and electrolytes in the surrounding environment, which are the main causes of corrosion (Fig. 6).

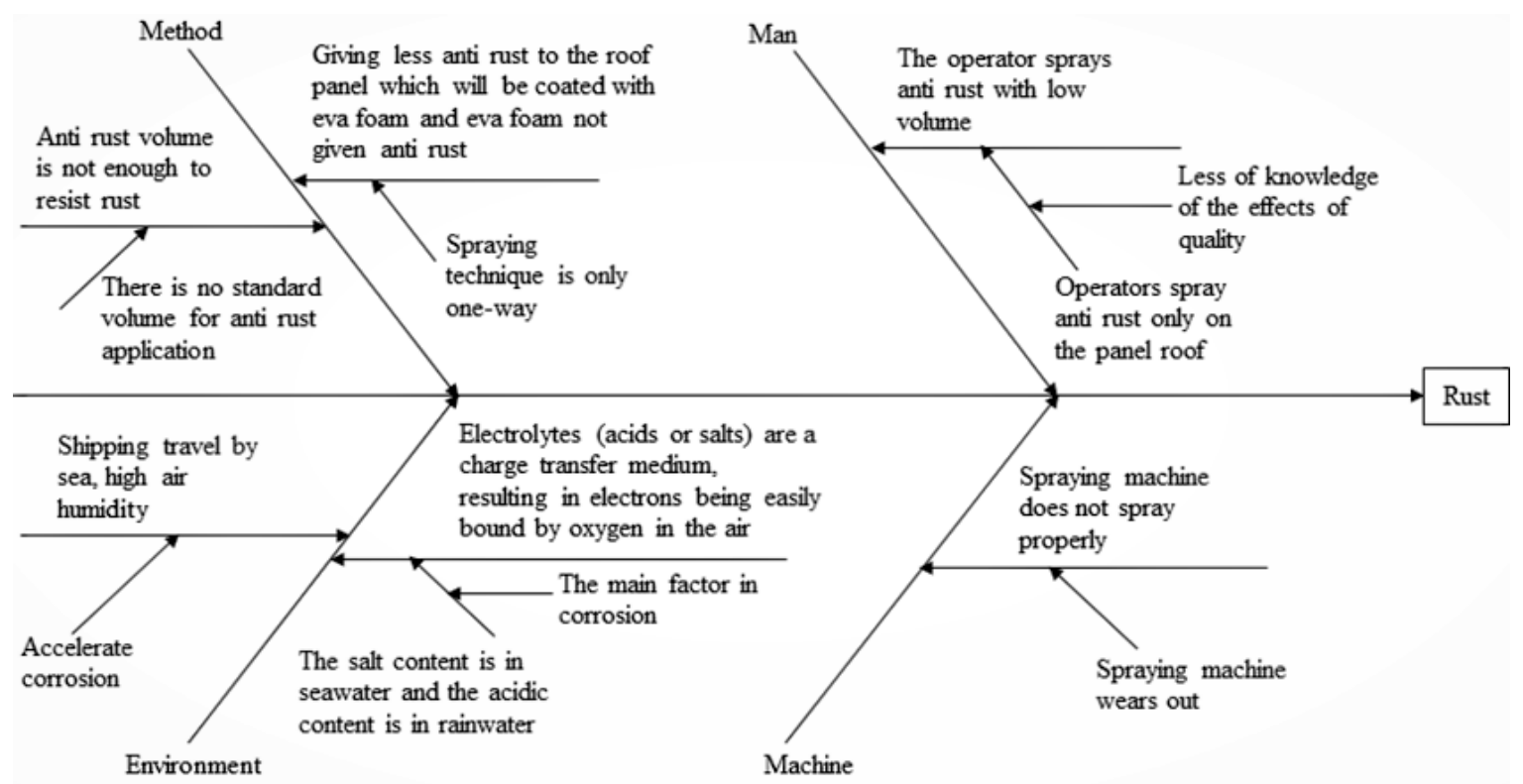

Fig. 6. Fishbone diagram rust 
Table 1. Improvement plans using the $5 \mathrm{~W}+1 \mathrm{H}$ method

\begin{tabular}{|c|c|c|c|c|c|}
\hline What & Why & How & Where & Who & When \\
\hline $\begin{array}{l}\text { Less operator } \\
\text { knowledge about } \\
\text { the effects of } \\
\text { quality }\end{array}$ & $\begin{array}{l}\text { For the operator to know } \\
\text { the effects of quality due to } \\
\text { the application of the } \\
\text { minimum volume of anti- } \\
\text { rust, it is necessary to } \\
\text { provide knowledge about } \\
\text { the impact of quality } \\
\text { effects }\end{array}$ & $\begin{array}{l}\text { Provides knowledge } \\
\text { about the impact of the } \\
\text { quality effect, at least } \\
\text { giving anti-rust volume to } \\
\text { the panel roof }\end{array}$ & $\begin{array}{l}\text { On the } \\
\text { CEVD line }\end{array}$ & $\begin{array}{l}\text { Line Head } \\
\text { Proses } \\
\text { Packaging }\end{array}$ & $\begin{array}{l}\text { In } \\
\text { March } \\
2019\end{array}$ \\
\hline $\begin{array}{l}\text { Spraying } \\
\text { technique is only } \\
\text { one-way }\end{array}$ & $\begin{array}{l}\text { For sufficient anti-rust } \\
\text { spraying on the roof and } \\
\text { Eva foam panels, an anti- } \\
\text { rust spraying SOP is } \\
\text { required }\end{array}$ & $\begin{array}{lr}\text { Making } & \text { Standard } \\
\text { Operating } & \text { Procedures } \\
\text { regarding } & \text { anti-rust } \\
\text { spraying steps } & \text { on panel } \\
\text { roof and Eva foam }\end{array}$ & $\begin{array}{l}\text { On the } \\
\text { CEVD line }\end{array}$ & $\begin{array}{l}\text { Operator, } \\
\text { Line Head, } \\
\text { Packing } \\
\text { spec. } \\
\text { engineering }\end{array}$ & $\begin{array}{l}\text { In } \\
\text { March } \\
2019\end{array}$ \\
\hline $\begin{array}{l}\text { There is no } \\
\text { standard volume } \\
\text { for anti-rust } \\
\text { application }\end{array}$ & $\begin{array}{l}\text { For the anti-rust } \\
\text { application to match the } \\
\text { volume, it is necessary to } \\
\text { make a standard volume of } \\
\text { anti-rust application on the } \\
\text { part }\end{array}$ & $\begin{array}{l}\text { Make the standard anti- } \\
\text { rust application volume }\end{array}$ & $\begin{array}{l}\text { On the } \\
\text { CEVD line }\end{array}$ & $\begin{array}{l}\text { Operator, } \\
\text { Line Head, } \\
\text { Packing } \\
\text { spec. } \\
\text { engineering }\end{array}$ & $\begin{array}{l}\text { In } \\
\text { March } \\
2019\end{array}$ \\
\hline $\begin{array}{l}\text { Spraying machine } \\
\text { wears out }\end{array}$ & $\begin{array}{l}\text { So that the spraying } \\
\text { machine does not wear out, } \\
\text { it is necessary to make a } \\
\text { standardization schedule } \\
\text { for the replacement of the } \\
\text { spraying machine }\end{array}$ & $\begin{array}{l}\text { Standardize the schedule } \\
\text { for changing the spraying } \\
\text { machine }\end{array}$ & $\begin{array}{l}\text { On the } \\
\text { CEVD line }\end{array}$ & Operator & $\begin{array}{l}\text { In } \\
\text { March } \\
2019\end{array}$ \\
\hline $\begin{array}{l}\text { Accelerate } \\
\text { corrosion }\end{array}$ & $\begin{array}{l}\text { To anticipate the potential } \\
\text { for rust caused by humidity } \\
\text { in the sea, it is necessary to } \\
\text { add anti-rust to the part }\end{array}$ & $\begin{array}{l}\text { Provides additional anti- } \\
\text { rust on parts, especially } \\
\text { those with a high potential } \\
\text { for rust }\end{array}$ & $\begin{array}{l}\text { On the } \\
\text { CEVD line }\end{array}$ & Operator & $\begin{array}{l}\text { In } \\
\text { March } \\
2019\end{array}$ \\
\hline $\begin{array}{l}\text { The main factor in } \\
\text { corrosion }\end{array}$ & $\begin{array}{l}\text { To anticipate the potential } \\
\text { for rust caused by } \\
\text { electrolytes in the } \\
\text { surrounding environment, } \\
\text { it is necessary to add anti- } \\
\text { rust to the part }\end{array}$ & $\begin{array}{l}\text { Provides additional anti- } \\
\text { rust on parts, especially } \\
\text { those with a high potential } \\
\text { for rust }\end{array}$ & $\begin{array}{l}\text { On the } \\
\text { CEVD line }\end{array}$ & Operator & $\begin{array}{l}\text { In } \\
\text { March } \\
2019\end{array}$ \\
\hline
\end{tabular}

\subsection{Improve phase}

Based on the analysis results in the previous stage, repair of the rust defect types can be done using the $5 \mathrm{~W}+1 \mathrm{H}$ method, developing a plan for improvement and quality improvement. The table of quality improvement plans for rust defect types can be seen in Table 1 .

Based on the repair plan results using $5 \mathrm{~W}+$ $1 \mathrm{H}$, the proposed improvements that can be made to reduce the type of rust defects in the roof panel packaging process are by making an anti-rust spraying SOP. Proposed improvements that have been identified based on the $5 \mathrm{~W}+1 \mathrm{H}$ Method in Table 1 are followed by implementing corrective actions on controllable factors. The corrective action that has been taken to minimize the number of defects in roof panel products is to create an anti-rust spraying SOP. The results of the proposed anti-rust spraying steps can be seen in Fig. 7.

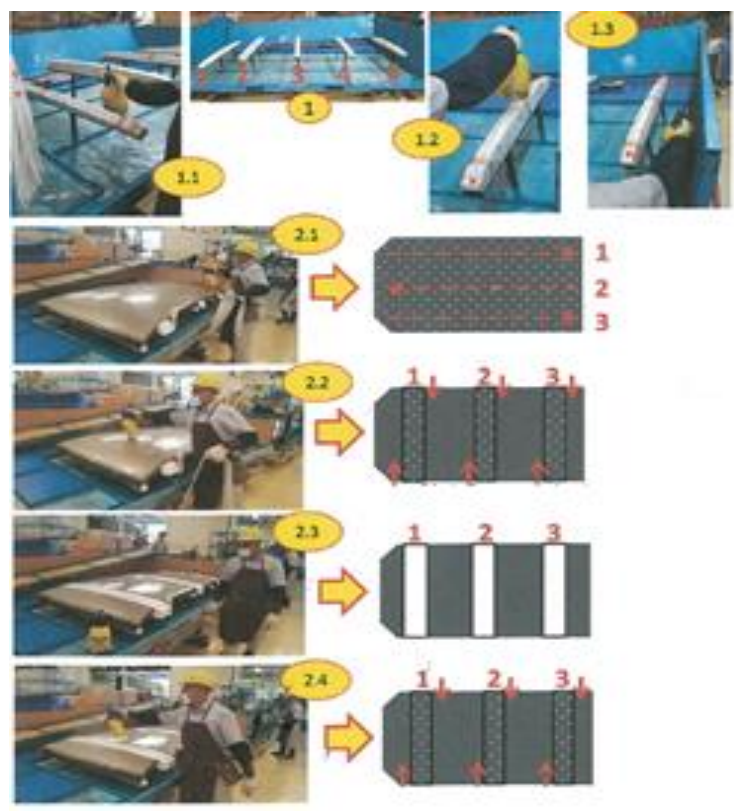

Fig. 7. Anti-rust spraying steps. 
The steps for anti-rust spraying can be described as follows:

a. (Point 1.1) Spray anti-rust oil on foam inner panel roof number 1 along the foam surface on the top and left side.

b. (Point 1.2) Spray anti-rust oil on foam inner panel roof numbers 2,3 , and 4 along the foam surface on the top side.

c. (Point 1.3) Spray anti-rust oil on foam inner panel roof number 5 along the foam surface on the top and right side.

d. (Point 2.1) Spray anti-rust oil 1 layer evenly on the surface of the roof panel part.

e. (Point 2.2) Spray 2 layers of anti-rust oil evenly on 3 points in the area where $1 \mathrm{G}$ foam sheet will be installed.

f. (Point 2.3) Install 3 pcs of $1 \mathrm{G}$ foam sheet.

g. (Point 2.4) Spray 2 layers of anti-rust oil evenly on each surface of $1 \mathrm{G}$ foam sheet.

\subsection{Control phase}

In this control phase, creating a $\mathrm{p}$ control chart after implementing the repair with rust defect data for May 2019 and finding out the DPMO value and Sigma Level after the improvement is done. The results of calculations with the P control chart after the repair show the results are still within control limits so that the improvements made can be controlled statistically (Fig. 8).

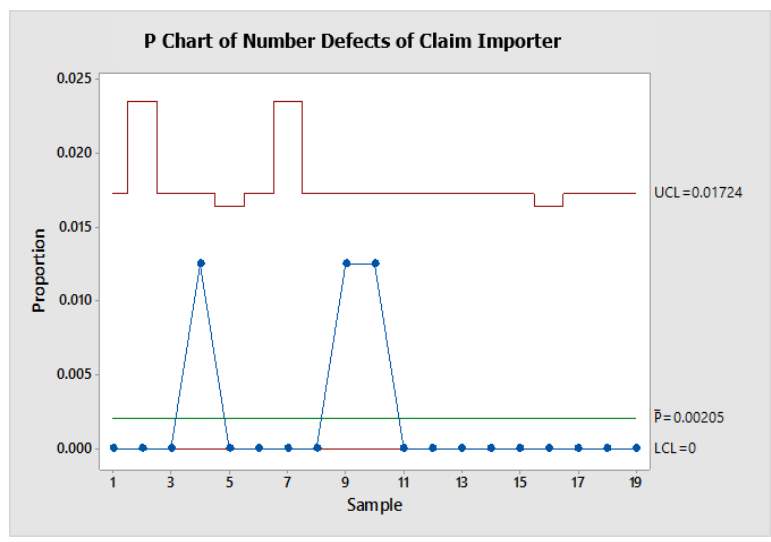

Fig. 8. P Control after improvement

Comparing the DPMO value and sigma level before improvement and after improvement. The amount of DPMO and sigma level before and after the improvement is shown in Table 2. The DPMO value has decreased after repairs have been made. The amount of reduction in DPMO after improvements was 31.450 units, and the Sigma Level increase was 1.04 .
Table 2. Comparison of DPMO and sigma levels before and after improvement

\begin{tabular}{cccc}
\hline $\begin{array}{c}\text { Performance } \\
\text { Baseline }\end{array}$ & $\begin{array}{c}\text { Before } \\
\text { Improvement }\end{array}$ & $\begin{array}{c}\text { After } \\
\text { Improvement }\end{array}$ & Difference \\
\hline DPMO & 33,500 & 2,050 & 31,450 \\
Level Sigma & 3.33 & 4.37 & 1.04 \\
\hline
\end{tabular}

The four-block diagram shows that it is included in the $\mathrm{C}$ quadrant with a Sigma Level value of 3.33 (Fig. 9). These results show that control is good, but on the other hand, technology there are still deficiencies or weaknesses (process control is good, poor technology). After improvement by making SOP for anti-rust spraying, the sigma level increased to $4.37 \sigma$ entered in the D quadrant so that it can be interpreted that the control process and technology are already included in the world class quadrant.

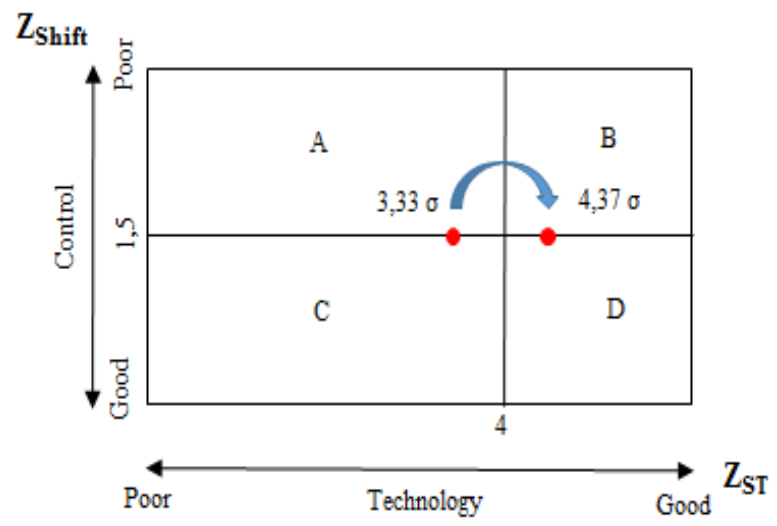

Fig. 9. Four block diagram

Most of the automotive manufacturing industry in Indonesia is in the middle and large sectors. In operational activities, it is necessary to control it so that it can run effectively and efficiently. This case study has provided a future direction for the automotive manufacturing industry to apply the DMAIC method and move forward to achieve a competitive advantage. These case studies will guide similar industries to achieve operational excellence and become more competitive. Apart from reducing defects from the process, this case study's implications are to reduce process costs and increase productivity and customer complaints. The foremost challenge in implementing DMAIC is maintaining the results that have been achieved [25] and many organizational-related factors that cause difficulty achieving similar results many times [26]. The results of the standardization carried out aim to ensure that the program can be sustainable [27]. 
This case study also implies that for the successful implementation of the DMAIC methodology, top management support is one of the critical success factors.

\section{CONCLUSION}

Based on the analysis and discussion described, the conclusions obtained from the causes of rust defects in the roof panel packaging process at PT TMMIN are human factors, method factors, machine factors, and environmental factors. A suggestion for improvements that can be made to reduce the type of rust defects in the roof panel packaging process is by making an antirust spraying SOP. The improvement results show a decrease in the value of DPMO from 33,500 units to 31,450 units and an increase in Sigma Level, namely 1.04 , from 3.33 to 4.37 . This research can be continued in future research by applying the Lean Six Sigma method. Lean Six Sigma method that integrates Lean with Six Sigma. Future research will focus more on reducing waste of causes of defects to get even better results.

\section{ACKNOWLEDGMENT}

The author would like to express his deepest appreciation to all relevant parties who have helped and supported the data for this research. Similar thanks go to the anonymous editors and reviewers.

\section{REFERENCES}

[1] A. Banawi and M. M. Bilec, "A framework to improve construction processes: Integrating Lean, Green and Six Sigma," Int. J. Constr. Manag., vol. 14, no. 1, pp. 45-55, Jan. 2014, doi: 10.1080/15623599.2013.875266.

[2] A. Yadav and V. K. Sukhwani, "Quality improvement by using six sigma DMAIC in an industry," Int. J. Curr. Eng. Technol., vol. 6, no. 6, pp. 41-46, 2016, Available: https://inpressco.com/wpcontent/uploads/2016/10/Paper104146.pdf.

[3] A. Roy, E. Henrik, and T. Håkan, "Similarities and differences between TQM, six sigma and lean," TQM Mag., vol. 18 , no. 3, pp. 282-296, Jan. 2006, doi: 10.1108/09544780610660004.

[4] V. Gaspersz, Lean Six Sigma. Jakarta:
Gramedia Pustaka Utama, 2007.

Available:

https://books.google.co.id/books?id=-

APoYfWmr7AC.

[5] P. S. Pande, R. P. Neuman, and R. R. Cavanagh, The Six Sigma Way: How GE, Motorola, and Other Top Companies are Honing Their Performance. McGraw-Hill Education, $2000 . \quad$ Available: https://books.google.co.id/books?id=ybOu vzveqTAC.

[6] J. E. Brady and T. T. Allen, "Six Sigma Literature: A Review and Agenda for Future Research," Qual. Reliab. Eng. Int., vol. 22, no. 3, pp. 335-367, Apr. 2006, doi: 10.1002/qre.769.

[7] K. Sameer, S. Erika, and T. Douglas, "Improved service system design using Six Sigma DMAIC for a major US consumer electronics and appliance retailer," Int. $J$. Retail Distrib. Manag., vol. 36, no. 12, pp. 970-994, Jan. 2008, doi: 10.1108/09590550810919388.

[8] A. V., A. Jiju, and D. Alex, "Observation: a Lean tool for improving the effectiveness of Lean Six Sigma," TQM J., vol. 24, no. 3, pp. 275-287, Jan. 2012, doi: $10.1108 / 17542731211226781$.

[9] S. Vikas and V. S., "Deploying Lean Six Sigma framework in an automotive component manufacturing organization," Int. J. Lean Six Sigma, vol. 7, no. 3, pp. 267-293, Jan. 2016, doi: 10.1108/IJLSS06-2015-0023.

[10] E. Megawati, P. A. Wicaksono, and D. Nurkertamanda, "Reducing defect in furniture industry using a lean six sigma approach," in AIP Conference Proceedings, 2020, vol. 2217, no. 1, p. 030180, doi: 10.1063/5.0004282.

[11] M. C. Prieto-avalos, C. R. Navarrogonzalez, A. Gonzalez-angeles, and S. V. Medina-leon, "Reduction Waste by Combining Lean Manufacturing and Six Sigma in an Electronics Industry," Res. J. Appl. Sci. Eng. Technol., vol. 8, no. 13, pp. 1558-1562, Oct. 2014, doi: 10.19026/rjaset.8.1133.

[12] C. L. Jung, "Implementing Six Sigma within Kaizen events, the experience of AIDC in Taiwan," TQM J., vol. 30, no. 1, pp. 43-53, Jan. 2018, doi: 10.1108/TQM02-2017-0017. 
[13] E. V Gijo, A. Jiju, and S. M. Vijaya, "Application of Lean Six Sigma in IT support services - a case study," TQM J., vol. 31, no. 3, pp. 417-435, Jan. 2019, doi: 10.1108/TQM-11-2018-0168.

[14] G. E.V. and S. Ashok, "Application of Six Sigma to improve the quality of the road for wind turbine installation," TQM J., vol. 25, no. 3, pp. 244-258, Jan. 2013, doi: 10.1108/17542731311307438.

[15] K. Srinivasan, S. Muthu, S. R. Devadasan, and C. Sugumaran, "Enhancement of sigma level in the manufacturing of furnace nozzle through DMAIC approach of Six Sigma: a case study," Prod. Plan. Control, vol. 27, no. 10, pp. 810-822, Jul. 2016, doi:

10.1080/09537287.2016.1143130.

[16] P. Jirasukprasert, J. Arturo Garza-Reyes, V. Kumar, and M. K. Lim, "A Six Sigma and DMAIC application for the reduction of defects in a rubber gloves manufacturing process," Int. J. Lean Six Sigma, vol. 5, no. 1, pp. 2-21, 2014, doi: 10.1108/IJLSS-03-2013-0020.

[17] N. Nelfiyanti, A. M. Rani, and A. Fauzi, "Implementasi Six Sigma untuk Perbaikan Kualitas Produk Kiwi Paste Berdasarkan Keluhan Pelanggan," J. Sist. dan Manaj. Ind., vol. 2, no. 1, pp. 41-50, Jul. 2018, doi: 10.30656/jsmi.v2i1.609.

[18] J. P. Costa, I. S. Lopes, and J. P. Brito, "Six Sigma application for quality improvement of the pin insertion process," Procedia Manuf., vol. 38, pp. 1592-1599, 2019, doi: 10.1016/j.promfg.2020.01.126.

[19] H. Saeid, Z. S. Mojib, and M. R. Jafri, "Application of Six Sigma DMAIC methodology in plain yogurt production process," Int. J. Lean Six Sigma, vol. 9, no. 4, pp. 562-578, Jan. 2018, doi: 10.1108/IJLSS-11-2016-0069.

[20] V. Iwan, H. T. Kim, S. Nurhadi, A. N. Indah, and P. F. Mega, "Halal six sigma framework for defects reduction," Journal of Islamic Marketing, vol. ahead-of-p, no. ahead-of-print. Jan. 01, 2020, doi: 10.1108/JIMA-11-2019-0232.

[21] A. Subhan, "Optimalisasi Proses Produksi Celana Panjang Melalui Pendekatan Six Sigma," J. Sist. dan Manaj. Ind., vol. 2, no. 1, pp. 23-32, Jul. 2018, doi: 10.30656/jsmi.v2i1.559.

[22] S. Mahendru and B. Singh, "DMAICMeasuring the PVC Pipe Manufacturing Process," Am. J. Econ. Financ. Manag., vol. 1, no. 4, pp. 293-303, 2015. Available: http://files.aiscience.org/journal/article/pd f/70220003.pdf.

[23] R. Sharma, P. Gupta, and V. Saini, "Six sigma DMAIC Methodology Implementation in Automobile industry: A case study," J. Manuf. Eng., vol. 13, no. 1, pp. 42-50, 2018. Available: http://smenec.org/wpcontent/uploads/Mar2018-v13-i1Raman.pdf.

[24] S. Krishna Priya, V. Jayakumar, and S. Suresh Kumar, "Defect analysis and lean six sigma implementation experience in an automotive assembly line," Mater. Today Proc., vol. 22, pp. 948-958, 2020, doi: 10.1016/j.matpr.2019.11.139.

[25] E. V. Gijo and J. Scaria, "Reducing rejection and rework by application of Six Sigma methodology in manufacturing process," Int. J. Six Sigma Compet. Advant., vol. 6, no. 1/2, pp. 77-90, 2010, doi: 10.1504/IJSSCA.2010.034857.

[26] E. V Gijo and T. S. Rao, "Six Sigma implementation - Hurdles and more hurdles," Total Qual. Manag. Bus. Excell., vol. 16, no. 6, pp. 721-725, Aug. 2005, doi: 10.1080/14783360500077542.

[27] M. Kaushik, G. Chauhan, K. Mathiyazhagan, R. Ojha, and M. Kumar, "Reducing rejections using Six Sigma: a case from Indian automobile component manufacturing industry," Int. J. Serv. Oper. Manag., vol. 33, no. 1, pp. 69-86, 2019, doi: 10.1504/IJSOM.2019.099655. 